\title{
Improving Content Knowledge in Social Studies for Upper Elementary Students
}

\author{
Caitlin Dalton ${ }^{1} \&$ Joshua Cuevas ${ }^{2}$
}

${ }^{1 \& 2}$ University of North Georgia, USA

Correspondence: Joshua Cuevas, University of North Georgia, USA.

Email: jocue24@yahoo.com

Received: December 21, 2018 Accepted: January 20, $2019 \quad$ Online Published: March 1, 2019

doi: $10.23918 /$ ijsses.v5i3p18

\begin{abstract}
This study investigated the effects of the instructional method Promoting Acceleration of Comprehension and Content through Text (PACT) on the social studies content acquisition, reading comprehension, and attitudes towards socials studies in fourth grade students. The use of PACT has been investigated heavily in middle-school and high school social studies classes, shown to consistently produce positive results in content acquisition and retention in these two age groups. PACT was administered to the treatment group. It was found to increase content acquisition in the treatment group by a statistically significant margin. No effect was found on student attitudes. Inconsistent results were found in reading comprehension. ANCOVA were used to analyze pre/post-test data on content test, reading comprehension articles from ReadWorks, and Attitudes Towards Social Studies survey. PACT seems to have had a positive impact on student content acquisition.
\end{abstract}

Keywords: PACT, Social Studies, Elementary Education, Primary Sources, Reading Comprehension

\section{Literature Review}

Public school teachers within the state of Georgia are expected to teach to the Georgia Standards of Excellence (Georgia Department of Education, n.d. a). These state standards address the scope of American history over the course of three years, beginning in third grade. Each year of study integrates all four strands (history, geography, civics/government, and economics), with a focus on map skills and integrating information from all four strands in problem solving. The goal of social studies education has long been to create effective citizens and a population that can use historical knowledge to inform its direction. In the 1890's, two committees within the American Historical Association released reports insisting on the importance of analytical, inquiry-based instructional practices (Bolinger \& Warren, 2007).

VanSledright (2004) describes the critical components of historical thinking to be identifying the nature of a source of historical evidence, judging the perspective of an author of a particular source, assessing the reliability of a source especially as it relates to other sources in the same time period, and recognizing that sources are constructed for a particular purpose. The author states that we should not hold elementary children to this standard which is set for expert and professional historians, but that it is the job of the history teacher to begin guiding students in the pursuit of these understandings and to draw nearer these goals as the students mature. 


\section{The Problem with Social Studies}

Despite these worthy goals, Willis (2007) found that time spent on social studies instruction has been minimized in favor of language arts and mathematics because of increasing pressure from standardized testing. This reduced instructional time diminished the scope of content covered and often saw less emphasis on higher order thinking within the content area. Willis suggests that the increased focus on accountability which was intended to improve student outcomes is undermining students' deep understanding of their social studies curriculum. Two decades ago, Barton (1997) found that even in classrooms which embrace active involvement in the social studies content, students seldom thought critically about the sources of information without direction. Students also had difficulty making connections between their conclusions about historical phenomenon and the evidence which supported it. More recently, Roberts and Brugar (2014) used interviews to investigate the depth of student geographic knowledge in diverse elementary schools. The researchers found that although the majority of students could name the elements of a map and some general purposes of maps, students were unable to identify the purpose of specific maps which contained political, historical, or geographic information in keys or captions. In one example, students were asked to identify the purpose of a map, then shown an image depicting South America with a color coded key for its various biomes. Multiple students replied that maps helped you find your way around a town. These effects were more pronounced in students from lower socioeconomic strata. These findings further indicate a dearth of critical thinking instruction in social studies instruction.

Hedrick, Harmon, and Linerode (2004) found a disturbing disparity between teachers' reported beliefs about the significance of social studies instruction and their reported practices. Teachers believed strongly in the importance of critical thinking, interacting with the content, and deep understandings of historical phenomenon. However, their practices were more in line with traditional, sometimes less effective, methods of instruction. Bolinger and Warren (2007) also found a significant lag between current social studies instruction theory and current practice. While teachers acknowledge and even herald the use of role play and debate as teaching strategies, in practice they continue to use passive, less effective methods, such as lecture based instruction. The authors suggest that the teachers' diminished use of active learning strategies and emphasis on critical thinking are heavily influenced by the structure of state assessments.

\section{PACT}

The instructional intervention Promoting Acceleration of Comprehension and Content Through Text (PACT) was designed to improve content acquisition and critical thinking skills through active student engagement with primary and secondary sources (Vaughn et al., 2013). The components of this instructional method were heavily influenced by the Direct and Inferential Mediation (DIME) model and the Landscape model. The DIME model emphasizes background knowledge, inferencing, strategies, and vocabulary in reading instruction. The Landscape model of text comprehension emphasizes memorybased and constructivist approaches to reading comprehension. The researchers had found previous positive effects from a constructivist and strategy-based approach to reading intervention (Vaughn et al., 2011) and chose to apply the methods to the integrated content areas of reading comprehension and social studies instruction. 
To date, numerous studies have examined the efficacy of PACT within the context of middle and high school classrooms (Vaughn et al., 2015; Vaughn et al., 2017; Wanzek et al. 2014; Wanzek et al. 2015; Wanzek, Swanson, Vaughn, Roberts, \& Fall, 2016). In these previous studies, the authors found a statistically significant gain in content-specific reading comprehension, content acquisition and retention over traditional lecture based instructional methods. One study on PACT also observed a small increase in general reading comprehension, but no other study has been able to replicate this finding (Vaughn, et al., 2013). Roberts et al. (2014) found that PACT increased content recall and hypothesized that this was due to the higher levels of observed metacognitive elaboration in the group of students which experienced PACT. Wanzek et al. (2014) found that students who scored in the lowest tier on the pretest for content acquisition during the PACT treatment did not benefit from the treatment, while overall the effect size for the treated population was substantial.

In a qualitative study, VanSledright (2002) further underscores the importance of actively engaging with historical concepts through performance tasks and metacognitive rehearsal. VanSledright saw the goal of history education as developing the students' ability to use judgements about the interconnectivity of historical events to refine their interpretations of history. Like in PACT, the subjects of this study analyzed historical documents and focused on a large concept as a focus to their units of study. All subjects saw gains in their ability to make judgements about historical events, but, like Wanzek et al. (2014), Vansledright found that the biggest impact was for students who were already moderate or high achieving.

\subsection{Aspects of PACT}

PACT consists of five components which may be divided into three categories and are strongly supported by research.

\subsection{Comprehension Canopy}

Within the structure of PACT, the Comprehension Canopy serves the purpose of unifying the unit of study through an essential question. (Vaughn et al., 2015; Vaughn et al., 2017; Wanzek et al., 2016; Wanzek et al., 2014; Wanzek et al., 2015). Jorgensen (1995) describes the purpose of essential questions as not only guiding and unifying a unit of study, but also providing an inclusive challenge for all learners. These open ended questions also force students to become investigators and think deeply about the content presented. Wilhelm (2014) argues that too often teachers engage in "authoritative discourse," wherein students are forced to guess at or grasp for answers that an authority figure already knows. His answer to this negative power dynamic is for teachers to assist students in moving towards independence and an authority of their own as meaning-makers. This is done through thoughtfully composed questions which guide student discovery and challenge them to create the answer for themselves, since there is no one right answer.

McTighe and Brown (2005) suggest that to be truly successful academically and in their lives beyond school, students must achieve a deep understanding of the content and critical thinking skills. The authors support the use of backward design to develop goals and essential questions for each unit of study which will guide students through performance tasks. Ritchhart (2012), in contrast, argues that the nature of the question is irrelevant. A high level or low level question may be spun by the teacher into a 
complex investigation. As such, the most thought provoking questions are worthless if not appropriately used to engage students and fuel discussion. Teachers cannot simply craft a question and leave students to answer it. It is the educator's role to guide discussion and discovery.

\subsection{Essential Words}

Cromley and Azevedo (2007) found that background knowledge and vocabulary had the largest effect on student reading comprehension, leading them to create the DIME model, which heavily influenced PACT. Their findings also led them to suggest that the best way to begin any academic reading may be to build up a student's applicable vocabulary and background knowledge. By prioritizing these two components of comprehension, educators give students the ability to make further inferences and deeper understandings.

Often upper grades teachers restrict their vocabulary instruction to activities which do not help students place them meaningfully in context with the lesson. Hairrell, Simmons, Rupley, and Vaughn (2011) found that most often teachers relegated their vocabulary instruction to copying definitions from a dictionary or textbook, or activities unrelated to meaning such as spelling key words repeatedly. When the researchers provided professional development on effective content-area vocabulary integration, teachers provided far more meaningful vocabulary instruction such as vocabulary maps, discussions, and example/non-example activities. Teachers who received vocabulary strategy development also spent an increased amount of time on explicit vocabulary instruction, nearly 15 minutes of their 40 minute social studies segment.

Weinburgh, et al. (2014) found significant growth in student academic vocabulary over a relatively short amount of treatment time. The treatment in this study did not "front-load" definitions, but rather allowed students to come across target vocabulary words naturally in the course of reading and hands-on exploration. As each target word was discovered, it was highlighted, and the definition explicitly taught and discussed. The program also made use of a Word Wall for the essential academic vocabulary. Although allowing the words to be discovered naturally differs from other studies, the instructional techniques are similar to those used in PACT and those used by Hairrell, et al. (2011).

Another study, which supported similar instructional techniques to those used in PACT, was conducted very recently by Solís, Scammacca, Barth, and Roberts (2017). The treatment in this study utilized vocabulary instruction through a simplified definition, pictures of concepts, connections to related words, and sample sentences. Although treatment was only administered over a very short period (eight 30 minute sessions), researchers saw significant gains in students' academic vocabulary, indicating the impact of direct vocabulary instruction.

\subsection{Team Based Learning}

There is a growing educational trend to begin incorporating collaboration into the standard practices in public school. Hettler (2015) suggests that this is a positive trend, finding a small but statistically significant positive effect when students, particularly minority and low socioeconomic status students, participated in a team-based learning course (TBL). Hettler compared student achievement and affective 
characteristics for students participating in TBL courses with those in lecture-based and technology dependent courses.

Michaelsen, Sweet, and Parmalee (2009) describe the purpose of TBL as ensuring that students do more than simply receive information. Instead, students spend the majority of class time developing conceptual and procedural knowledge while collaborating to solve problems with real-life application. The authors emphasize four key components to promote effective TBL; groups, accountability, feedback, and assignment design. Groups must be heterogenous and properly managed to ensure all participants are engaged and benefiting. Students must receive instructive feedback frequently and rapidly after assignment checkpoints or completion. This promotes content retention and strengthens group development. There must be a system for holding students accountable for individual and group work. Group assignments must be designed to promote learning and collaboration.

In a systematic review of literature on TBL, Haidet, Kubitz, and McCormack (2014) found that although TBL has existed for more than 30 years, it has only recently begun to gain wider acceptance. The authors found that there is a rapidly growing pool of scholarly work on the topic, as the movement becomes more popular. Based on their research, the authors were cautiously optimistic in declaring that the method had promise but needed further experimental trials. The authors also note that many teachers have difficulty embracing this method as it requires them to relinquish their role as the sole purveyor of knowledge.

There are, however, potential drawbacks to this method of instruction. Wanzek et al. (2014) found that the lowest performing students showed no improvement in content acquisition in the TBL instructional condition or control. The authors hypothesize that the short nature of the instructional unit (10 days) prevented students with little prior knowledge from grasping core concepts as quickly as the students with some prior knowledge.

\subsection{Assessing Social Studies}

It would seem the most common method of assessing social studies knowledge is through multiple choice tests. Georgia state assessments of social studies consist of multiple choice questions (Georgia Department of Education, n.d. b). Prior studies on PACT have utilized the Gates-MacGinitie reading comprehension subtest and the Assessment of Social Studies Knowledge (ASK) as measures, both consisting of multiple option comprehension and recall questions (Vaughn et al., 2013; Vaughn et al., 2015; Vaughn et al., 2017; Wanzek et al., 2016; Wanzek et al. 2015; Wanzek et al., 2014). However, Mooney and Lastrapes (2016) investigated which methods of knowledge assessment best predicted social studies achievement as measured by the SAT-10. The researchers found that the best predictor of social studies achievement was by using periodic assessments with Daze, a fill in the blank reading passage for the content area, not a multiple choice test.

Because of the heavy emphasis the constructivist approach places on vocabulary acquisition, one must consider the most effective method of assessing vocabulary, especially the depth of vocabulary knowledge. Depth of vocabulary knowledge refers to a student's understanding and ability to use a term and its associated concepts across a variety of contexts (Anderson \& Freebody, 1982; Nagy, Herman, \& Anderson, 1985). A student's ability to apply words to multiple situations and understand their several 
meanings and shades is critical to their success as a reader. In fact, many of the words encountered by elementary school children have multiple meanings (Johnson, Moe \& Bauman, 1983). Truly understanding a word involves much more than being able to relay a definition. Students must be aware of a words several dimensions, be able to understand it in context and correctly use the word in context.

\section{Research Questions}

The use of PACT (Promoting Acceleration of Comprehension and Content Through Text) as an instructional method has been investigated heavily in middle-school and high school social studies classes with replicated findings. It has been shown to consistently produce positive results in content acquisition and retention in these two age groups. Previous studies have found some inconsistent support for the improvement of content area reading comprehension but not for the improvement of overall reading comprehension. PACT consists of three basic elements; Comprehension Canopy, which guides investigation, Essential Words, the vocabulary that is necessary to access the content, and Team Based Learning, when students engage in meaningful conversation and construct knowledge together.

This study is designed to investigate the merit of extending this specific instructional method to upper elementary grades. Given the substantial gains demonstrated in other studies on this technique, as well as the evidence that the content is better retained when taught with this technique, it is imperative to learn whether this particular lesson structure can be equally effective in the upper elementary setting. The study will seek to answer the following questions: Does the use of PACT improve content acquisition and retention when used with fourth grade social studies students? Does PACT improve text-specific reading comprehension when used with these students? Does PACT improve the acquisition and retention of explicitly taught content specific vocabulary words? Does PACT improve student performance on word association tasks? Does PACT impact student motivation in Social Studies? These findings could indicate whether this technique is well suited to students below middle school.

\section{Method}

\subsection{Contextual Factors}

The study was conducted in a suburban county located 30 miles from Atlanta that is known for its high performing schools. The county is quickly growing in size and diversity. The student population consists of more than 46,000 students with White 65.22\%, Asian 15.21\%, Hispanic 12.94\%, Black 3.39\%, Multi-Racial 2.79\%, and Other students less than 1\% (Forsyth County Schools, 2016). Countywide, schools enjoy adequate funding and strong levels of parent and community support.

The elementary school in which this study was conducted is among the smallest and oldest schools in this county. The student body consisted of just 640 students and spanned state funded Pre-K to 5th grade (Dasher, n.d.). The student population is very diverse in its socioeconomic status. Many parents at this school are employed as doctors, engineers, and other highly skilled professions, yet approximately $27.8 \%$ of the student population is classified as economically disadvantaged. The student body was $64 \%$ White, 6\% Asian, 19\% Hispanic, 5\% African American, and 6\% other. The school hosts a large portion of the county's self-contained autism program; therefore, the special education percentage was much 
higher than a typical population at $18.1 \%$. Students classified as Limited English proficiency were $13.7 \%$ of the student population.

Teachers; All four teachers (all female) were certified by the state and held bachelor's degrees; three of the teachers also held graduate degrees. Teaching experience ranged from seven to 15 years $(M=10.5$ years). All teachers taught every academic subject to their homeroom students.

Students; The sample consisted of 108 fourth grade students divided among four classrooms with an average class size of 27 . These four classes comprised the entirety of the school's fourth grade. Special education students made up $14.8 \%$ of the fourth-grade population but were not included in the sample. Gifted students were placed in two classrooms, separate from the special education inclusion classrooms. Gifted students represented $8.3 \%$ of the sample. The racial diversity of the grade level somewhat mirrored the school population with 53.8\% White, 16.6\% Asian, 21.2\% Hispanic, 4.7\% African American, and $3.7 \%$ other. Of the fourth-grade students, $19 \%$ received free or reduced lunch. English Language Learners, who comprised $13.8 \%$ of the sample, were primarily concentrated in one of the gifted classrooms. This group was included in the treatment group. The four classes were divided into the treatment group and control group. The treatment group was comprised of 28 students, 6 of whom were gifted identified and 8 of whom were ELL. The control group was comprised of 68 students distributed amongst 3 classrooms. The students in these three classrooms represented 7 gifted students, 2 ELL, and 59 general education students. The control group also hosted the special education population for the grade, but their data was not considered.

\section{Materials and Measures}

\subsection{Assessment of Social Studies Content Knowledge}

The pretest and posttest for this study covered Georgia 4th grade social studies standards for the two units taught (Building a Government and Westward Expansion). The test was untimed and consisted of three sections. The first section was 20 , four-option multiple-choice questions. This was made by the researcher to represent a cross-section of the standards in each unit. These items equally represented the two units, with ten questions per unit. The second section consisted of four vocabulary items. Each vocabulary item provided a sentence containing one of the Essential Words in a meaningful context. Two words from each unit were selected. The vocabulary word was underlined within the sentence. The students were asked to provide an open-ended definition for each underlined word. The final section consisted of two short answer questions with one question per unit. Every vocabulary and short answer question was graded by two teachers from the fourth-grade team to establish interrater reliability. If the graders could not agree, a third teacher was brought in. These teachers underwent training on the scoring scale for accuracy and use of the Essential Words. The pretest was given two weeks prior to beginning the first unit. The posttest was administered after the final unit. The question order was randomized, creating two separate forms of the same test. Approximately one half of participants used each form during the testing, and none of the students used the same form twice. 


\subsection{Text-Specific Comprehension Measure}

Students were given the same nonfiction passages the week prior to beginning a unit and again the day after the completion of each unit to measure their text-specific comprehension. The content of each passage reflected the unit of instruction (Building a Government and Westward Expansion). Passages and reading comprehension questions were drawn from ReadWorks (2012a, b), a cognitive science based reading resource, and used with permission. After each passage, students answered ten multiple choice questions to assess their reading comprehension. The passages were at approximately the same reading level as measured by Lexile $(M=713)$.

\subsection{Attitudes towards Social Studies}

Students were asked to rate their attitudes towards Social Studies using questions drawn from The Attitudes toward Mathematics Inventory, with the words "Social Studies" substituted for mathematics terms (Tapia \& Marsh, 2004). The survey used also reduced the number of items from 40 to a more developmentally appropriate 15 . Items were rated on a 5-point Likert scale with students indicating their range of agreement with the statement. The three constructs assessed were attitudes toward social studies, perceived usefulness of social studies, and perception of own social studies ability. Tapia and Marsh (2004) found the reliability coefficient alpha of this instrument was .97 in all grade levels.

\section{Procedures}

All four of the fourth-grade classrooms in the school participated in this study. The control group consisted of two special education inclusion classes (although the special education students did not participate) and one class of high achieving and gifted students. Teachers in the control group continued to use their typical teaching practices. The treatment group consisted of one classroom, which contained ELL and high achieving and gifted students. Classrooms were assigned to the treatment or control group at the direction of school administration. All consented students in each class were administered a battery of assessments by the teacher prior to the unit instruction (within five days prior to day one of the first unit). Teachers administered two units (Building a Government and Westward Expansion) to both the treatment and comparison students during their regularly scheduled Social Studies period. In the comparison classes, the teachers taught the two units using their typical practices, which included lecture, note taking, and hands-on activities. In the treatment class, the teacher implemented Promoting Acceleration of Comprehension and Content through Text during each of the units. Teachers taught the same content and topics to both the treatment and comparison conditions. Each of the two units consisted of 10 days of instruction with one school day for assessment between units. The duration of the study was five weeks between pretesting and final posttest. Only the implementation of PACT, not the content or curriculum, differed between the classes. Social Studies lessons were 45 minutes and instruction occurred daily. Following the completion of the units, all students were assessed with the complete set of posttest measures within one week of the last day of the unit. Affective measures of motivation and interest in the form of surveys were taken during the pretest and after the completion of both

units. 


\subsection{Professional Development and Support}

All teachers attended a one-hour professional development session concerning the design of the study and the importance of maintaining fidelity to assigned teaching strategy.

\subsection{Comparison Group}

Students in this group completed all pretest and posttest measures, but teachers used the form of instruction they had been accustomed to using. From interviews with the teachers, their previous social studies teaching strategies mainly consisted of lecture with the students taking notes, independent reading from social studies textbooks, some hands-on activities, and brief educational videos with multiple choice or fill-in-the-blank viewing guides. These teachers indicated that they rarely revisited vocabulary after initial introduction except during the unit review. Teachers also indicated that they did not use team-based interactive readings and never used team-based learning comprehension checks. From reviewing the lesson plans provided by the teachers within the control group, the most common content acquisition was note taking based on a power point or video. This represented about $40 \%$ of instructional time, as indicated by lesson plans. Less frequently teachers utilized independent, internetbased research activities called "web quests." The most frequently used content application activity was cut and paste information organizers, with social studies books and the notes taken as references. Teachers covered the same three units as the treatment group (Building a Government, Westward Expansion, and Civil War) with 10 days spent on each unit.

\subsection{Treatment Group}

The teacher in the treatment group administered the three, ten-day units using PACT. There are five critical components of the PACT intervention; Comprehension Canopy, Essential Words, Knowledge Acquisition, Team Based Learning Comprehension Checks, and Team Based Learning Knowledge Application.

\subsection{Comprehension Canopy}

On the first day of each ten-day unit, the teacher began building background knowledge and provided direction for the unit of study. The first day of instruction was centered around a short, high-interest video clip. Before showing the video, the teacher gave the video purpose by posing a task such as "While watching the video, write down three factors that led to the Civil War." After viewing the video clip and completing their task, students engaged in small group discussion. In their discussion, students shared their findings from the video task as well as answered other comprehension questions from the teacher intended to relate previous knowledge to new content. Finally, the teacher posed a complex question such as "Was the American Civil War inevitable? Why or why not?", to be called the Comprehension Canopy (CC) Question. This question guided the discussion of the remainder of the unit. At the beginning of each lesson for the remainder of the unit, teachers briefly reviewed the CC question and facilitated a short discussion on how the new information related to the answer of the CC question. This review of the $\mathrm{CC}$ allowed students to view new knowledge gained during the unit and provided a guide for the acquisition of future knowledge. On the final day of the unit, students answered 
the CC question in writing. All three CCs maybe found in Appendix A.

\subsection{Essential Words}

Throughout the 10-day unit, five high-frequency concept words were taught. Examples include "assimilation" in the Westward Expansion unit or "secession" in the Civil War unit. These Essential Words were incorporated in texts, comprehension checks, discussions, and knowledge application tasks. During the first lesson of the unit, the teacher provided a simple definition for each word, a visual, several related words, a sentence providing context, and turn-and-talk discussion prompts. Each day for the remainder of the unit, the teacher included a brief overview of one of the words during the Comprehension Canopy review.

\subsection{Knowledge Acquisition}

There were two knowledge acquisition sessions during each 10-day unit. In each of these sessions, students focused on core concepts identified by state standards through the use of primary and secondary text sources. Students read for approximately 20 minutes per session. Students read texts as a class or in pre-established heterogeneous teams of four or five students. These readings were paired with discussion and note taking to help students connect the content to the Comprehension Canopy and Essential Words.

\subsection{Team Based Learning Comprehension Checks}

Students completed two short comprehension checks in each unit. These provided the teacher with formative data to inform instruction within the unit and assess student understanding of content. These Team Based Learning Comprehension Checks consisted of five multiple choice content questions, two fill-in-the-blank vocabulary tasks, and one short open-ended writing question, given on days 5 and 7 of the unit. The purpose of the Team Based Learning Comprehension Checks was to assess the students' understanding of core concepts and promote individual accountability. The comprehension checks were completed individually, with no access to resources, and submitted to the teacher for a grade. This allowed the teacher to assess the students' progress individually. Next, the students moved into their teams. The comprehension checks were completed a second time as a team with access to resources, including text and notes, with the requirements that all team members must agree on an answer. The teams were required to provide evidence from the notes or text to support their chosen answer. The team comprehension checks were completed in a Google form which provided immediate feedback if the wrong answer was selected. If the wrong answer was selected, students had to go back to their resources and find evidence for a different answer. During the team-based comprehension checks, the teacher circulated to monitor progress and encourage participation, use of text, and productive conversations. This provided the teacher with another opportunity to identify concepts that were misunderstood. The teacher spent about 10 minutes reviewing the misunderstood concepts at the end of the lesson. 


\subsection{Team Based Learning Knowledge Application}

During the final two days of the 10-day unit, students worked in their teams to complete an application activity which required them to clarify, apply, and extend their understanding of the core concepts and texts. These activities were designed to encourage students to use the knowledge gained from the unit to solve problems and develop conclusions. Students were first given a short text, then given an assignment that connected all aspects of the unit, including the Comprehension Canopy and Essential Words. For example, during the Westward Expansion unit, students read journal entries from William Clayton (1847) detailing his encounters with Native Americans. Students then used this text, combined with previous knowledge and resources, to list at least five ways westward expansion affected the Native American population. Next, students were asked to prepare a pamphlet to persuade or dissuade settlers from journeying west using details from the texts they had read in their final product. During this collaboration, the teacher circulated to encourage teams to engage in productive conversations, form and support their reasoning, and prepare to present their work to the class. After these products had been presented to the class by the group, students discussed as a whole group the final answer to the Comprehension Canopy question.

\section{Results}

\subsection{Main Effects of Treatment on Student Achievement}

\subsubsection{Content Knowledge}

To determine if there was a difference in content acquisition in the two units of instruction between the comparison and treatment groups, student test scores on the teacher created ASK were analyzed. An ANCOVA was run on the scores for both groups, using ASK post-test scores as the dependent variable and pretest scores as the covariate. Condition was the grouping variable. At posttest, students in the treatment group outperformed students in the comparison group on the ASK knowledge acquisition by a statistically significant margin $(p<.001)$. The means and standard deviations may be found in Table 1 .

Table 1: Content Acquisition Results Means and Standard Deviations

\begin{tabular}{|l|r|r|}
\hline Group & Means & Std Deviation \\
\hline Treatment & 18.04 & 28 \\
\hline Control & 14.24 & 71 \\
\hline Total & 15.16 & 99 \\
\hline
\end{tabular}


Table 2 :Content Acquisition Results ANCOVA Table

\begin{tabular}{|l|l|l|l|l|l|l|}
\hline Source & $\begin{array}{c}\text { Type III Sum } \\
\text { of Squares }\end{array}$ & df & F & $\begin{array}{c}\text { Mean } \\
\text { Square }\end{array}$ & Sig. & Effect size \\
\hline Corrected Model & $728.690 \mathrm{a}$ & 3 & 19.227 & 242.897 & 0 & 0.375 \\
\hline Intercept & 452.7 & 1 & 35.835 & 452.7 & 0 & 0.272 \\
\hline PreCont & 207.144 & 1 & 16.397 & 207.144 & 0 & 0.146 \\
\hline TreatmentControl & 354.314 & 2 & 14.024 & 177.157 & 0 & 0.226 \\
\hline Error & 1212.75 & 96 & & 12.633 & & \\
\hline Total & 24924 & 100 & & & & \\
\hline Corrected Total & 1941.44 & 99 & & & & \\
\hline
\end{tabular}

a. $\mathrm{R}$ Squared $=.375($ Adjusted R Squared $=.356) p<.001$

\subsubsection{Reading Comprehension}

To determine if there was a difference in text specific reading comprehension growth between the comparison and treatment groups, student comprehension test scores on the unit specific ReadWorks article were analyzed for each unit. The same article was used as the pretest and post-test measures for each unit. An ANCOVA was run on the scores for both groups, using reading post-test scores as the dependent variable and reading pretest scores as the covariate. Condition was the grouping variable. On the reading comprehension measure for the first unit, students in the treatment group outperformed students in the control group by a small, but statistically significant margin $(p=.003)$ of 1.91 points. The means and standard deviations for this comprehension measure may be found in Table 3 . Full ANCOVA statistics for this measure may be found in Table 4. 
Table 3: Unit 1 Reading Comprehension Means and Standard Deviations

\begin{tabular}{|l|r|r|r|}
\hline & Means & Std Deviation & $\mathrm{N}$ \\
\hline Treatment & 65.71 & 17.09 & 28 \\
\hline Control & 63.8 & 20.309 & 71 \\
\hline Total & 63.7 & 20.333 & 99 \\
\hline
\end{tabular}

Table 4: Unit 1 Reading Comprehension ANCOVA results

\begin{tabular}{|c|c|c|c|c|c|c|}
\hline Source & $\begin{array}{l}\text { Type III Sum } \\
\text { of Squares }\end{array}$ & df & $\mathrm{F}$ & $\begin{array}{l}\text { Mean } \\
\text { Square }\end{array}$ & Sig. & Effect Size \\
\hline Corrected Model & $11213.442 \mathrm{a}$ & 3 & 12.075 & 3737.814 & 0 & 0.274 \\
\hline Intercept & 6411.998 & 1 & 20.713 & 6411.998 & 0 & 0.177 \\
\hline PreArt1 & 7041.396 & 1 & 22.747 & 7041.396 & 0 & 0.192 \\
\hline TreatmentControl & 3933.891 & 2 & 6.354 & 1966.946 & 0.003 & 0.117 \\
\hline Error & 29717.558 & 96 & & 309.558 & & \\
\hline Total & 446700 & 100 & & & & \\
\hline Corrected Total & 40931 & 99 & & & & \\
\hline
\end{tabular}

a. R Squared $=.274($ Adjusted R Squared $=.251)$

On the reading comprehension measure for the second unit, the control group outperformed the treatment group by a statistically significant $(p=.04)$ of 5.15 points. The means and standard deviations for this comprehension measure may be found in Table 5. Full ANCOVA statistics for this measure may be found in Table 6 . 
Table 5: Unit 2 Reading Comprehension Means and Standard Deviations

\begin{tabular}{|l|r|r|r|}
\hline Group & Means & Std Deviation & $\mathrm{N}$ \\
\hline Treatment & 59.64 & 19.904 & 28 \\
Control & 64.79 & 21.305 & 71 \\
\hline Total & 62.7 & 21.782 & 99 \\
\hline
\end{tabular}

Table 6: Unit 2 Reading Comprehension ANCOVA results

\begin{tabular}{|l|r|r|r|r|r|r|}
\hline Source & $\begin{array}{c}\text { Type III Sum of } \\
\text { Squares }\end{array}$ & $\mathrm{df}$ & $\mathrm{F}$ & $\begin{array}{c}\text { Mean } \\
\text { Square }\end{array}$ & Sig. & $\begin{array}{c}\text { Effect } \\
\text { size }\end{array}$ \\
\hline Corrected Model & $10159.682 \mathrm{a}$ & 3 & 8.832 & 3386.561 & 0 & 0.216 \\
\hline Intercept & 6662.667 & 1 & 17.376 & 6662.667 & 0 & 0.153 \\
PreArt2 & 5656.942 & 1 & 14.753 & 5656.942 & 0 & 0.133 \\
\hline TreatmentControl & 2560.629 & 2 & 3.339 & 1280.314 & 0.04 & 0.065 \\
\hline Error & 36811.318 & 96 & & 383.451 & & \\
\hline Total & 440100 & 100 & & & & \\
\hline Corrected Total & 46971 & 99 & & & & \\
\hline
\end{tabular}

a. $\mathrm{R}$ Squared $=.216($ Adjusted $\mathrm{R}$ Squared $=.192)$

Next, an ANCOVA was run to compare change in text specific reading comprehension, but controlled for academic status (gifted, second language learner, or general education). Condition was the grouping variable. The dependent variable was the post-test reading scores. The covariates were their pre-test reading scores and ESOL, general education, or Gifted status. For the first unit's reading comprehension measure, the treatment group outperformed the control group by a statistically significant margin $(p=$ .001 ) of 3.34 points. The means and standard deviations for this comprehension measure may be found in Table 7. Full ANCOVA statistics for this measure may be found in Table 8. For the reading comprehension measure in unit 2 , there was no statistically significant difference between groups $(p=$ $.178)$. 
Table 7: Unit 1 Reading Comprehension Means and Standard Deviations Controlled for Academic status

\begin{tabular}{|l|r|r|r|}
\hline Group & Means & Std Deviation & N \\
\hline Treatment & 67.14 & 14.62 & \\
\hline Control & 63.8 & 20.309 & \\
\hline Total & 64.1 & 19.853 & \\
\hline
\end{tabular}

Table 8: Unit 1 Reading Comprehension for Academic status ANCOVA results

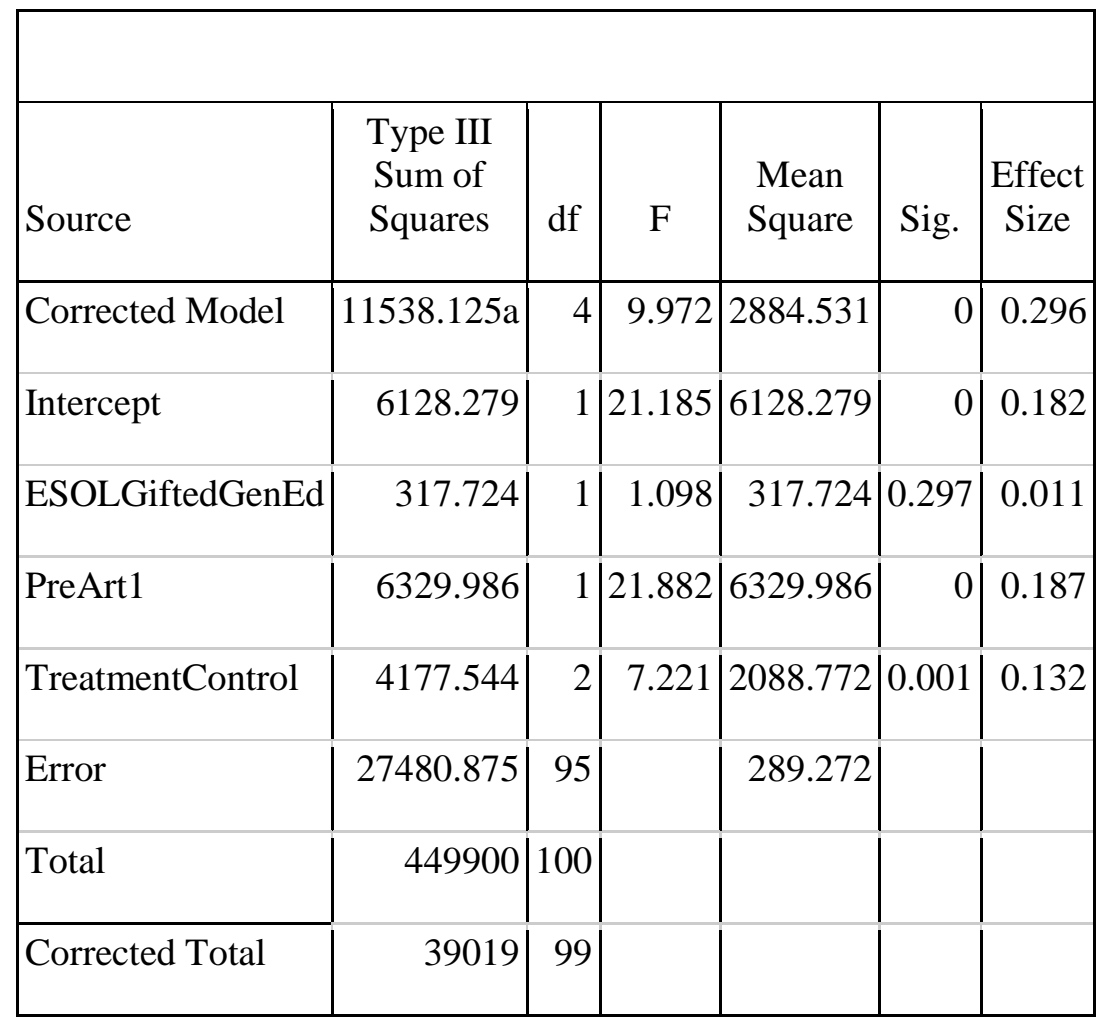

a. $\quad$ R Squared $=.296$ (Adjusted R Squared $=.266)$

\subsubsection{Affective Traits}

One research question was designed to determine whether the implementation of PACT would influence student attitudes towards social studies. Constructs (value, security, and enjoyment) were measured with 
survey data. An ANCOVA was run to compare change in each construct. Condition was the grouping variable. The dependent variable for the analysis for each construct was post-survey scores, while the covariate was their pre-survey scores. At posttest, there was no statistically significant difference between students in the control and treatment groups on any measure.

Construct 1- Value. An ANCOVA was run to compare change in perception of value. Condition was the grouping variable. The dependent variable was post-survey scores for value, while the covariate was their pre-survey scores for value. There was not a significant difference between the groups, $p=.36$.

Construct 2- Security. An ANCOVA was run to compare change in perception of security. Condition was the grouping variable. The dependent variable was post-survey scores for security, while the covariate was their pre-survey scores for security. There was not a significant difference between the groups, $p=.222$.

Construct 3- Enjoyment. An ANCOVA was run to compare change in enjoyment. Condition was the grouping variable. The dependent variable was post-survey scores for enjoyment, while the covariate was their pre-survey scores for enjoyment. There was not a statistically significant difference between the groups, $p=.249$.

\section{Discussion}

The purpose of this study was to examine the effects of the PACT intervention implemented in a fourthgrade classroom. Overall, following two instructional units in social studies classes, students in the PACT intervention significantly improved their content knowledge. Students in classes receiving the PACT intervention performed approximately one standard deviation higher than students receiving typical social studies instruction in the same content (3.8 points on average). These findings provide support for the PACT intervention as a method to substantially improve students' content knowledge acquisition in fourth-grade social studies classrooms. The effect size (effect size $=.226, p<.001$ ) is notable especially because of the short duration of the intervention, with PACT being implemented in only two instructional units. Vaughn et al. (2013) found an effect size of .17 for content acquisition, while Vaughn et al. (2015) found an effect size of .32 for content acquisition. Both studies examined PACT with $8^{\text {th }}$ grade students over the course of an instructional year. Wanzek et al. (2014) found an effect size of .19 for $11^{\text {th }}$ grade students. The results of longer term studies on older subject put this study's findings within the same range.

The PACT intervention provided inconsistent results in student's reading comprehension. When the test scores were controlled for academic status (gifted, general education, or second language learner), one unit reading comprehension measure showed statistically significant gains for the treatment group and the other did not show any statistically significant difference. It was hypothesized that the intervention's focus on text in the social studies domain would improve students' comprehension of novel social studies text. The findings partially supported this hypothesis. This could be a result of the short duration of the treatment, however several studies which looked at the impact of reading comprehension with PACT found no improvement (Vaughn et al., 2015, Wanzek et al. 2014, Wanzek, Swanson, Vaughn, Roberts, \& Fall, 2016) over the control groups, despite longer treatment times. Although one study 
(Vaughn, et al. 2013) found improvement in reading comprehension with this intervention, that finding has not been replicated.

It was hypothesized that the treatment's focus on making connections between concepts would improve student attitudes towards social studies. The findings do not support this hypothesis, as there was no statistically significant difference in the attitudes of students between the treatment and control groups when controlling for initial attitude levels. Anecdotal observations from the teacher implementing the intervention noted the students expressed displeasure when the Team Based Learning routine was announced. After the first two sessions of TBL, some students grumbled or complained when the they were asked to move into teams. The students who were noted to object most often were those who already disliked social studies (based on their enjoyment surveys) and often struggled academically in other academic areas in addition to social studies. However, these sentiments do not appear to have impacted their attitudes towards social studies in general in any statistically significant way. This could be because their reaction would have been the same to any other independent social studies activities and therefore did not indicate a change in attitude.

\section{Limitations}

There are several limitations of these findings. Convenience grouping was used, increasing the chance that the comparison and treatment groups were not equivalent. General education students can be considered randomly grouped only in that they were placed in classrooms somewhat randomly. Gifted students and second language learners were intentionally placed in specific rooms. However, the number of gifted learners in the treatment and comparison groupings were nearly equivalent. All results were controlled for prior knowledge, which helps mitigate this concern somewhat.

One control classroom hosted the majority of special education students for the grade and a co-teacher, which may have impacted content delivery. Since special education student data was not included and the comparison group was relatively large compared to the treatment group, this may not have had much impact on the statistical analysis.

Additionally, when regarding these results one must take into account the possibility of teacher effect. Since the treatment was administered by only one teacher, it is possible that the individual teacher unduly influenced the performance level seen based on teacher effect rather than strictly the treatment. This is somewhat mitigated by the fact that there were three teachers instructing in the comparison condition. However, we must still consider this possible implication.

The short duration of the treatment could have impacted the results of the study, although it likely dampened the results rather than exaggerating them. Other studies on this instructional method used months or years of data to drive their conclusions. (Vaughn et al., 2015; Vaughn et al., 2017; Wanzek et al. 2014; Wanzek et al. 2015; Wanzek, Swanson, Vaughn, Roberts, \& Fall, 2016)

Several factors impact the potential generalizability of the results. The relatively small sample size and the lack of special education students in the sample make it difficult to identify how well this intervention will apply to other populations. Additionally, this study was performed at only one school in 
the suburbs. This limits the researcher's ability to extend any support for this instructional method to urban or rural schools.

\section{Implications for Further Study}

The results of this study suggest that this instructional method may be appropriate for upper elementary students. Despite the limited duration of the treatment, students showed statistically significant growth in their content acquisition. This would suggest the need for further research to support or refute the use of PACT in the classroom. Studies of a longer duration should be done to examine the long-term impact of PACT on the retention of content knowledge. Studies of PACT with older students indicated that students who were instructed with this method retained the content better than students who received more traditional methods of instruction (Vaughn et al., 2015; Vaughn et al., 2017; Wanzek et al. 2014; Wanzek et al. 2015; Wanzek, Swanson, Vaughn, Roberts, \& Fall, 2016). This study was unable to examine content retention due to time constraints, so this would also need to be examined. Additionally, studies should be conducted with larger and more diverse samples. Ideally a large, randomized sample of fourth and fifth-grade students in multiple schools, ranging from urban to rural, would be conducted over the course of a school year to examine the impact on content acquisition and retention, as well as reading comprehension and attitudes towards social studies.

The results of this study do not support an impact on reading comprehension or affective traits. Further studies should continue to monitor both of these aspects, to ensure that the younger age group does not incur negative impacts in these areas due to PACT.

\section{References}

Anderson, R. C., Freebody, P., Illinois Univ., U. R., \& Bolt, B. M. (1982). Reading

comprehension and the assessment and acquisition of word knowledge. Technical Report No. 249. Retrieved from https://www.ideals.illinois.edu/bitstream/handle/2142/17540/ctrstreadtechrepv01982i00249_op t.pdf?sequence $=1$

Barton, K. C. (1997). "I just kinda know": Elementary students' ideas about historical evidence. Theory and Research in Social Education, 25(4), 407-30.

Bolinger, K., \& Warren, W. J. (2007). Methods practiced in social studies instruction: A review of public school teachers' strategies. International Journal of Social Education, 22(1), 68-84.

Cromley, J. G., \& Azevedo, R. (2007). Testing and refining the direct and inferential mediation model of reading comprehension. Journal of Educational Psychology, 99, 311-325. DOI: 10.1037/00220663.99.2.311

Dasher, J. (n.d.) K-12 Public schools report card-Indicators \& demographics. Retrieved from https://gaawards.gosa.ga.gov/analytics/saw.dll?PortalPages

Forsyth County Schools (2016) Retrieved from https://www.forsyth.k12.ga.us/site/Default.aspx?PageID=583

Georgia Department of Education (n.d. a) Georgia Milestones Assessment System. Retrieved from http://www.gadoe.org/Curriculum-Instruction-and-Assessment/Assessment/Pages/GeorgiaMilestones-Assessment-System.aspx

Georgia Department of Education (n.d. b) Georgia Standards of Excellence Retrieved from www.georgiastandards.org

Haidet, P., Kubitz, K., \& McCormack, W. T. (2014). Analysis of the team-based learning literature: TBL comes of age. Journal on Excellence In College Teaching, 25(3/4), 303-333. 
Hairrell, A., Simmons, D., Rupley, W., \& Vaughn, S. (2011). An investigation of fourth-grade teachers' use of vocabulary instruction in social studies. Journal of Reading Education, 36(3), 19-26.

Hedrick, W. B., Harmon, J. M., \& Linerode, P. M. (2004). Teachers' beliefs and practices of vocabulary instruction with social studies textbooks in grades 4-8. Reading Horizons, 45(2-), 103-125.

Hettler, P. (2015). Student demographics and the impact of team-based learning. International Advances in Economic Research, 21(4), 413-422.

Johnson, D., Moe, A., \& Baumann, J. (1983). 7th Ginn word book for teachers: A basic lexicon. Lexington, MA: Ginn.

Jorgensen, C. (1995). Essential questions-Inclusive answers. Educational Leadership, 52(4), 52-55.

McTighe, J., \& Brown, J. L. (2005). Differentiated instruction and educational standards: Is detente possible? Theory into Practice, 44(3), 234-244. doi:10.1207/s15430421tip4403_8

Michaelsen, L., Sweet, M. \& Parmalee, D. (2009) Team-based learning: Small group learning's next big step. New Directions in Teaching and Learning, 7-27.

Mooney, P., \& Lastrapes, R. E. (2016). The benchmarking capacity of a general outcome measure of academic language in science and social studies. Assessment for Effective Intervention, 41(4), 209-219. doi:10.1177/1534508415624648

Nagy, W. E., Herman, P. A., \& Anderson, R. C. (1985). Learning words from context. Reading Research Quarterly, 20(2), 233-253.

Read Works. (2012a). American Government - The Bill of Rights Part I. Retrieved from https://www.readworks.org/article/American-Government---The-Bill-of-Rights-PartI/9c54b60a-65ea-4ff3-a049-36111fdc5b00\#!articleTab:content/

Read Works. (2012b). Westward Expansion - The Oregon Trail. Retrieved from https://www.readworks.org/article/Westward-Expansion---The-Oregon-Trail/dd331583-b76b400d-a41f-7db4f25c71cc\#! articleTab:content/

Ritchhart, R. (2012) The real power of questions. Creative Teaching \& Learning, 2(4), 8-12.

Roberts, G., Scammacca, N., Osman, D., Hall, C., Mohammed, S., \& Vaughn, S. (2014).

Team-based learning: Moderating effects of metacognitive elaborative rehearsal and middle school history content recall. Educational Psychology Review, 26(3), 451. doi:10.1007/s10648-0149266-2

Roberts, K., \& Brugar, K. (2014). Navigating maps to support comprehension: When textbooks don't have GPS. The Geography Teacher, 11(4), 149-163. doi: 10.1080/19338341.2014.975143

Solís, M., Scammacca, N., Barth, A. E., \& Roberts, G. J. (2017). Text-based vocabulary intervention training study: Supporting fourth graders with low reading comprehension and learning disabilities. Learning Disabilities -- A Contemporary Journal, 15(1), 103.

Tapia, M. \& Marsh, G. E. (2004) An instrument to measure mathematics attitudes. Academic Exchange Quarterly, 8(2), 16-21.

VanSledright, B. A. (2002). Fifth graders investigating history in the classroom: Results from a researcher-practitioner design experiment. The Elementary School Journal, 103(2), 131-160. doi:10.1086/499720

VanSledright, B. A. (2004). What does it mean to think historically ... and how do you teach it? Social Education, 68(3), 230.

Vaughn, S., Martinez, L. R., Wanzek, J., Roberts, G., Swanson, E., \& Fall, A. (2017). Improving content knowledge and comprehension for English language learners: Findings from a randomized control trial. Journal of Educational Psychology, 109(1), 22-34. doi:10.1037/edu0000069

Vaughn, S., Roberts,G.,Swanson, E., Wanzek, J., Fall, A., Stillman-Sipsak, S. (2015, March). Improving middle-school students' knowledge and comprehension in social studies: A replication. Educational Psychology Review, 27, 31-50. doi:10.1007/s10648-014-9274-2

Vaughn, S., Swanson, E. A., Roberts, G., Wanzek, J., Stillman-Spisak, S. J., Solis, M., \& Simmons, D. (2013). Improving reading comprehension and social studies knowledge in middle school.

Reading Research Quarterly, 48(1), 77-93. 
Vaughn, S., Klingner, J. K., Swanson, E. A., Boardman, A. G., Roberts, G., Mohammed, S. S., \& Stillman-Spisak, S. J. (2011). Efficacy of collaborative strategic reading with middle school students. American Educational Research Journal, 48(4), 938-964.

Wanzek, J., Kent, S. C., Vaughn, S., Swanson, E. A., Roberts, G., \& Haynes, M. (2015). Implementing team-based learning in middle school social studies classes. Journal of Educational Research, 108(4), 331-344. doi:10.1080/00220671.2014.893224

Wanzek, J., Swanson, E., Vaughn, S., Roberts, G., \& Fall, A. (2016). English learner and non-english learner students with disabilities. Exceptional Children, 82(4), 428. doi:10.1177/0014402915619419

Wanzek, J., Vaughn, S., Kent, S. C., Swanson, E. A., Roberts, G., Haynes, M., \& Solis, M. (2014). The effects of team-based learning on social studies knowledge acquisition in high school. Journal of Research on Educational Effectiveness, 7(2), 183-204. doi:10.1080/19345747.2013.836765

Weinburgh, M., Silva, C., Smith, K., Groulx, J., \& Nettles, J. (2014). The intersection of inquiry-based science and language: Preparing teachers for ELL classrooms. Journal of Science Teacher Education, 25(5), 519-541. doi:10.1007/s10972-014-9389-9

Willis, J. S. (2007). Putting the squeeze on social studies: Managing teaching dilemmas in subject areas excluded from state testing. Teachers College Record, 109(8), 1980-2046.

Wilhelm, J. (2014) Learning to love the questions: How essential questions promote creativity and deep learning. Knowledge Quest, 42(5), 36-41. 


\section{Appendix A- Content Knowledge Assessment}

1. Who is known as the "Father of Our Country"?
a. Thomas Jefferson
b. George Washington
c. James Madison
d. George Mason

2. Who is known as the "Father of the Constitution"?
a. Thomas Jefferson
b. George Washington
c. James Madison
d. George Mason

3. Which document was the basis for the First Amendment to the Constitution of the United States, the amendment that protects religious freedom?
a. Declaration of Independence
b. Virginia Declaration of Rights
c. Virginia Statute for Religious Freedom
d. Bill of Rights

4. Who is the leader of the executive branch of government?
a. Speaker of the House
b. Attorney General
c. Secretary of State
d. President

5. A U.S. President is elected every years and can serve at most terms.
a. 6 years, 2 terms
b. $\quad 2$ years, unlimited terms
c. 4 years, 2 terms
d. 8 years, 8 terms

6. Congress members are
a. chosen by the president
b. approved or confirmed by the Supreme Court
c. elected by the people
d. Elected by sitting members of congress

7. The way our government keeps any one branch from having too much power is called
a. checks and balances
b. Monarchy
c. Federalism
d. patriotism 
8. The Great Compromise and the 3/5 Compromise were both resolved by the Delegates of the--
a. House of Burgesses
b. Continental Congress
c. Parliament
d. Constitutional Convention

9. What kind of congress did the Great Compromise establish?
a. 1 House that controls everything
b. 2 Houses that have no power
c. 2 Houses that both vote on laws
d. 2 Houses that take turns being in charge

10. The $3 / 5$ Compromise settled the argument of--
a. Representation in the Senate
b. How slaves should be counted for representation
c. How states should be represented
d. Borders of states

11. The army is funded through the federal system. Provide a definition of the Federal System.

12. When congress feels that someone in power has misused their power, they are able to impeach them. Provide a definition of impeach

13. How does the power of the federal government under the Constitution compare to the power of the government under the Articles of Confederation?

14. Which river did Lewis and Clark begin their journey in?
a) Mississippi
b) Columbia
c) Missouri
d) Savannah

15. How did Sacajawea help Lewis and Clark?

a) She fought on the side of the Native Americans.

b) She encouraged Lewis and Clark to go back to Georgia where it was safe.

c) She translated for Lewis and Clark and helped them cross the Rocky Mountains.

d) She helped them discover gold. 
16. What influence thousands of settlers to head west during the 1800's?
A. Life in the east was boring.
B. They government was giving away free land.
C. They wanted to be the first to reach the Pacific Ocean.
D. The government made them move.

17. Which of the following was a result in the Trail of Tears, a 1,000 mile journey?
A. 4,000 Cherokee Indians died along the way from cold, starvation, and disease.
B. 4,000 Coushatta Indians died along the way from heart attacks.
C. The Indians were given food and supplies along the way.
D. Some Indians were able to ride in cars to travel west.

18. How did the Homestead Act influence settlers to travel west?
A. To get British soldiers to leave their homes.
B. To get more towns built in the west.
C. To get free land from the government for those willing to build farms and homes.
D. To allow people to get gold.

19. What caused Napoleon, a leader of France, to sell the Louisiana Territory to Thomas Jefferson for $\$ 15$ million?

a) Napoleon needed the money for his war in Russia

b) Napoleon was frustrated that Spain had not fully transferred Louisiana to him yet. $\mathrm{He}$ wanted to sell the territory because it was useless to him.

c) Napoleon was trying to get the Americans to help him in his impending war on Spain and England, so he sold the Louisiana territory very cheaply to them.

d) Napoleon was afraid of what the American army would do if he said no to the sale of the Louisiana Territory.

20. How did the telegraph impact life in America?

a) It led to the development of the steamboat.

b) It caused the construction of the transcontinental railroad.

c) It allowed rapid communication across long distances.

d) It caused immigrants to move to the cities rather than the country.

21. In the early 1800's many changes were taking place in America. Which was the first invention to increase trade and travel?
a) Steamboat
b) Telegraph
c) Bi-plane
d) Model-T Ford

22. Many people traveled west to look for copper, gold, and silver. Which would have been true at the time?

a) Many pioneers struck it rich, expanding the local economy rapidly.

b) Most miners worked independently or in small groups with very few striking it rich.

c) Women were better at being miners, because of their keen eyesight. Most miners took their wives with them for this reason.

d) Miners were paid a salary for their work by large companies. 
23. What is the significance of the Battle of the Alamo?
a) This was a symbol of bravery.
b) The Texans wanted to fight what they believed in.
c) Gave them more reasons to break away from Mexico.
d) All of the above

24. What influence did Thomas Jefferson have on expanding our country?

25. Westward expansion rapidly changed the lives of settlers and Native Americans. Provide a definition of expansion.

26. The settlers travel beyond the Appalachian Mountains and onto the frontier. Provide a definition of frontier.

\section{Appendix B- Attitudes towards Social Studies Inventory}

Directions: This inventory consists of statements about your attitude toward mathematics. There are no correct or incorrect responses. Read each item carefully. Please think about how you feel about each item. Please answer every question.

Write the number in the box next to the question to show how much you agree or disagree with the sentence.

1-No WAY! Strongly Disagree

2- Hm, I don’t think so. Disagree

3-I don't agree or disagree

4- Yes, I agree

5- Absolutely! I strongly agree 


\begin{tabular}{|c|c|}
\hline 1 & $\begin{array}{l}\text { Social Studies is one of the most important things for people to } \\
\text { study. }\end{array}$ \\
\hline 2 & $\begin{array}{l}\text { I can think of many ways that I use Social Studies outside of } \\
\text { school. }\end{array}$ \\
\hline 3 & Studying Social Studies makes me feel nervous. \\
\hline 4 & I learn Social Studies easily \\
\hline 5 & Social Studies is one of my most worrying subjects. \\
\hline 6 & I really like Social Studies \\
\hline 7 & $\begin{array}{l}\text { My mind goes blank and I am unable to think clearly when } \\
\text { working with Social Studies. }\end{array}$ \\
\hline 8 & I am comfortable answering questions in math class. \\
\hline 9 & When I hear the word Social Studies, I have a feeling of dislike. \\
\hline $\begin{array}{l}1 \\
0\end{array}$ & I am happier in a Social Studies class than in any other class. \\
\hline $\begin{array}{l}1 \\
1\end{array}$ & Social Studies does not scare me at all \\
\hline $\begin{array}{l}1 \\
2\end{array}$ & I think I am good at Social Studies \\
\hline $\begin{array}{l}1 \\
3\end{array}$ & Social Studies classes are too hard \\
\hline $\begin{array}{l}1 \\
4\end{array}$ & Social Studies is boring \\
\hline $\begin{array}{l}1 \\
5\end{array}$ & I am always confused in my Social Studies class. \\
\hline
\end{tabular}

